\title{
Pengaruh Pemberian Jus Buah Jambu Biji Merah Terhadap Kadar Haemoglobin Dan Vozmax Pada Aktifitas Fisik Maksimal
}

\section{Fajar Apollo Sinaga}

\author{
Correspondence: Fakultas Ilmu Keolahragaan, Universitas Negeri Medan, \\ Medan, Indonesia \\ Email: sinagafajar@yahoo.com
}

\begin{abstract}
Abstrak
Aktifitas fisik dapat menyebabkan peningkatan produksi radikal bebas yang dapat mengakibatkan penurunan antioksidan sehingga mempengaruhi performance atlet akibat terjadi sport anemia. Radikal bebas dapat dicegah atau dikurangi dengan pemberian antioksidan. Telah diketahui buah jambu biji merah mengandung berbagai jenis antioksidan alami tetapi belum pernah diteliti khasiatnya untuk mengurangi produksi radikal bebas yang dipicu oleh aktifitas fisik. Tujuan penelitian adalah mengetahui efek pemberian jus jambu biji merah terhadap kadar haemoglobin dan $\mathrm{VO}_{2}$ max atlet pada aktifitas fisik maksimal. Jenis penelitian yang dilakukan adalah penelitian eksperimental dengan rancangan penelitian Randomized Control Group Pretest-Postest Design. Penelitian dilaksanakan di Stadion Universitas Negeri Medan dan Laboratorium Fisiologi FIK-UNIMED. Penelitian dilakukan selama 3 bulan. Populasi dan sampel penelitian adalah mahasiswa Ilmu Keolahragaan sebanyak 20 orang yang memenuhi kriteria yang dibagi menjadi 2 kelompok yaitu kelompok eksperimen dan kelompok kontrol. Pada penelitian dilakukan pengukuran kadar Haemoglobin dan $\mathrm{VO}_{2} \mathrm{Max}$ saat pre test dan post test. Hasil analisis data diperoleh bahwa pemberian jus jambu biji merah selama menjalani program latihan dapat meningkatkan kadar $\mathrm{Hb}$ dan $\mathrm{VO}_{2}$ max pada aktifitas fisik maksimal.
\end{abstract}

\section{Kata Kunci: Jambu Biji Merah, Haemoglobin, $\mathrm{VO}_{2} \mathrm{Max}$}

\section{Pendahuluan}

Aktifitas fisik dapat menyebabkan peningkatan produksi berbagai jenis radikal bebas yang dapat mengakibatkan kerusakan pada sel-sel (Dekany et al, 2008). Radikal bebas yang terbentuk di dalam tubuh akan dinetralkan oleh elaborasi sistem pertahanan antara antioksidan enzim-enzim seperti katalase (CAT), superoksid dismutase (SOD), glutation peroxidase (GPx) dan sejumlah anti oksidan non enzim termasuk diantaranya vitamin $\mathrm{A}, \mathrm{E}$ dan $\mathrm{C}$, glutatione, ubiquinone dan flavonoid (Urso, 2003). Pada saat produksi radikal bebas melebihi antioksidan pertahanan seluler maka dapat terjadi stres oksidatif (Daniel et al, 2010). Pada kondisi stres oksidatif, radikal bebas akan menyebabkan terjadinya peroksidasi lipid (Evans, 2000), kerusakan pada jaringan otot (Vina, et al., 2000) dan perubahan aktifitas antioksidan enzim (Urso, 2003) yang akhirnya dapat mempengaruhi performance atlet.

Hasil studi menunjukkan bahwa stres oksidatif adalah salah satu faktor yang bertanggung jawab terhadap kerusakan eritrosit selama dan setelah latihan 
fisik dan dapat menyebabkan anemia yang sering disebut "sport anemia" (Senturk et al, 2001) akibat turunnya kadar haemoglobin (Senturk, et al., 2005., Senturk, et al., 2004). dan juga menyebabkan kerusakan pada jaringan otot (Vina, et al., 2000). Kerusakan jaringan otot dan darah ini dianggap terlibat dalam proses kelelahan, atau ketidakmampuan untuk menghasilkan tenaga. Kerusakan akibat stres oksidatif juga dapat mengubah histokimia darah dan menyebabkan nyeri otot (Dekkers., et al 1996 dan Kuipers, 1994). Peningkatan radikal bebas akibat olahraga juga mempengaruhi jalur energi aerobik di dalam mitokondria, menyebabkan terjadinya kelelahan (Kendall dan Eston, 2002). Sementara itu menurut (Zhu dan Haas, 1997) bahwa penurunan $\mathrm{VO}_{2}$ max dapat terjadi pada penderita anemia dengan kadar Haemoglobin yang menurun dan konsekuensinya adalah menurunnya kapasitas transport oksigen di dalam darah sehingga dapat mempenagruhi performance atlet. Selain itu, akibat latihan fisik berat pada individu yang tidak terkondisi atau tidak terbiasa melakukan latihan fisik juga dapat mengakibatkan kerusakan oksidatif dan injuri otot (Evans, 2000).

Turunnya kadar antioksidan dan peroksidasi lipid yang berdampak kepada penurunan haemoglobin dan $\mathrm{VO}_{2}$ max akibat aktifitas fisik maksimal sejalan dengan pernyataan Colgan, 1986 yang mengemukakan bahwa bahwa atlet di bawah pelatihan berat dan kompetisi tidak mampu mempertahankan kadar antioksidan secara optimal pada jaringan. Sehubungan dengan itu, Gomez (2008) mengatakan kerusakan oksidatif akibat aktifitas fisik mungkin dapat dicegah dengan mengoptimalkan gizi, terutama dengan meningkatkan kandungan antioksidan makanan. Menurut Silalahi (2006) khasiat antioksidan akan lebih efektif bila mengkonsumsi sayur-sayuran atau buah-buahan yang kaya antioksidan dari berbagai jenis dari pada menggunakan antioksidan tunggal seperti vitamin E. Hal ini mungkin dikarenakan oleh adanya komponen lain dan interaksinya dalam sayur-sayuran dan buah-buahan yang berperan secara positif.

Salah satu alternatif bahan alam yang mempunyai kandungan antioksidan adalah buah jambu biji merah. Buah jambu biji merah diketahui mempunyai kandungan vitamin $\mathrm{C}$ lima kali lebih besar dibandingkan dengan buah jeruk (Kumar, 2012). Senyawa lain dalam buah jambu biji yang berfungsi sebagai antioksidan adalah karotenoid seperti beta-karoten, lycopene, beta-cryptoxanthin dan polifenol (Nascimento et al, 2010; Oliveira et al, 2010; Ordonez-Santos dan Vazquez-Riascos, 2010). Sebagai antioksidan, $\beta$-karoten bekerja menangkap radikal bebas terutama radikal peroksil dan hidroksil dan $\beta$-ka]ไroten bekerja sinergis dengan vitamin C dan E (Silalahi, 2006).

Keistimewaan buah jambu biji yang memiliki berbagai jenis antioksidan dan potensi aktivitas antioksidannya yang besar, membuat peneliti merasa tertarik dan perlu meneliti efek antioksidan buah jambu biji merah terhadap kadar Haemoglobin dan $\mathrm{VO}_{2}$ max atlet pada aktifitas fisik maksimal.

\section{Pustaka}

Radikal bebas adalah atom atau molekul yang memiliki elektron tidak berpasangan pada lapisan luarnya (Stankovic, 2012 ;Castrogiovanni, 2012). Sel secara rutin menghasilkan radikal bebas dan kelompok oksigen reaktif (reactive 
oxygen species/ROS) yang merupakan bagian dari proses metabolisme (Stankovic, 2012; Daniel et al, 2010; Urso, 2003). Dalam rangka mendapatkan stabilitas kimia, radikal bebas akan menyerang molekul stabil yang terdekat dan mengambil elektron, zat yang terambil elektronnya akan menjadi radikal bebas juga sehingga akan memulai suatu reaksi berantai, yang akhirnya terjadi kerusakan sel tersebut (Droge, 2002).

Radikal bebas dapat bereaksi dengan lemak, protein dan asam nukleat seluler, sehingga terjadi kerusakan lokal dan disfungsi organ tertentu. Lemak merupakan biomolekul yang rentan terhadap serangan radikal bebas. Peroksidasi lipid paling banyak terjadi di membran sel, terutama asam lemak tidak jenuh yang merupakan komponen penting penyusun membran sel. Malondialdehyde (MDA) adalah salah satu hasil dari peroksidasi lipid yang disebabkan oleh radikal bebas selama latihan fisik maksimal atau latihan daya tahan (endurance) dengan intensitas tinggi (Wang et al., 2008; Lyle et al., 2009, Sousa, 2006), sehingga MDA merupakan indikator umum yang digunakan untuk menentukan jumlah radikal bebas dan secara tidak langsung menilai kapasitas oksidan tubuh (Liang, 2008).

Antioksidan atau reduktor berfungsi untuk mencegah terjadinya oksidasi atau menetralkan senyawa yang telah teroksidasi, dengan cara menyumbangkan hidrogen dan atau elektron (Silalahi, 2006). Di dalam tubuh terdapat mekanisme antioksidan atau anti radikal bebas secara endogenik dimana radikal bebas yang terbentuk akan dinetralkan oleh elaborasi sistem pertahanan antara antioksidan enzim-enzim seperti katalase, superoksid dismutase, glutation peroxidase dan sejumlah anti oksidan non enzim termasuk diantaranya vitamin $\mathrm{A}, \mathrm{E}$ dan $\mathrm{C}$, glutatione, ubiquinone dan flavonoid (Christopher, 2004; Urso, 2003). Sistem pertahanan ini bekerja dengan beberapa cara antara lain berinteraksi langsung dengan radikal bebas, oksidan, atau oksigen tunggal, mencegah pembentukan senyawa oksigen reaktif, atau mengubah senyawa reaktif menjadi kurang reaktif (Winarsi, 2007).

Superoksida dismutase (SOD) ada di dalam sel, misalnya dalam sitosol dan mitokondria, serta dalam plasma. Dalam sitosol dan dalam plasma ada bentuk-bentuk SOD, yang terdiri dari tembaga dan seng: SOD 1 dan SOD $3(\mathrm{Cu}$, $\mathrm{Zn} \mathrm{SOD).} \mathrm{Di} \mathrm{mitokondria} \mathrm{ada} \mathrm{bentuk} \mathrm{SOD,} \mathrm{yang} \mathrm{terdiri} \mathrm{dari} \mathrm{ion} \mathrm{mangan} \mathrm{Mn}$ SOD). Semua bentuk SOD mengkatalisis reaksi anion superoksida dismutasi untuk hidrogen peroksida.

Fungsi utama dari enzim katalase adalah mengkatalisis reaksi $\mathrm{H}_{2} \mathrm{O}_{2}$ menjadi $\mathrm{H}_{2} \mathrm{O}$ dan $\mathrm{O}_{2}$. Enzim katalase bekerja mendukung aktifitas enzim SOD. Dalam melakukan aktifitas sebagai antioksidan, enzim katalase membutuhkan mineral-mineral penyusun, diantaranya: Copper $(\mathrm{Cu})$, zinc $(\mathrm{Zn})$, selenium $(\mathrm{Se})$, manganese $(\mathrm{Mn})$, serta besi $(\mathrm{Fe})$

Enzim Glutation peroksidase terutama terdapat dimitokondria. Mekanisme reaksi enzim gluthathion peroksidase merupakan salah satu cara utama yang digunakan oleh tubuh untuk melindungi diri dari kerusakan oksidatif. Enzim ini mengkatalisis reduksi hidrogen peroksida dan peroksida lemak (LOOH) oleh gluthathion ( $y$-glutamil sisteinilglisin). Gugus sulfhidril pada gluthathion (GSH)berfungsi sebagai donor elektron, dan oksidasi menjadi bentuk disulfida 
(GSSG) selama reaksi tersebut (Dawn dkk, 2000). Gluthathion peroksidase bekerja terutama dengan hidroperoksida organik, misalnya zat yang dihasilkan selama peroksidasi lemak di membran. Apabila disulfida telah terbentuk, disulfida di reduksi kembali menjadi bentuk sulfidril oleh gluthathion reduktase. Gluthathion reduktase memerlukan elektron dari NADPH, yang biasanya dihasilkan dari jalur pentosa fosfat (Perona, 1990)

Istilah Vitamin E sering digunakan untuk menyatakan setiap campuran dari tokoferol (Yunani: tokos = kelahiran; pheros = membawa). Tokoferol adalah inhibitor yang potensial terhadap lipida peroksidasi (Silalahi, 2006). $\alpha$-tokoferol merupakan bentuk tokoferol yang paling aktif dan paling penting untuk aktivitas biologi tubuh, sehingga aktivitas vitamin E diukur sebagai $\alpha$-tokoferol. Vitamin E merupakan pemutus rantai peroksida lemak pada membran. Vitamin E mengendalikan peroksida lemak dengan menyumbangkan ion hidrogen ke dalam reaksi, sehingga mengubah radikal peroksil (hasil peroksidasi lipid) menjadi radikal tokoferol yang kurang reaktif, menyekat aktivitas tambahan yang dilakukan oleh peroksida, sehingga memutus reaksi berantai dan bersifat membatasi kerusakan (Burton, 1994).

Vitamin $\mathrm{C}$ mempunyai nama lain yaitu L-ascorbic acid (C6H8O6). Nama kimia vitamin $\mathrm{C}$ adalah 2-oxo-L-threo-hexono-1,4-lactone-2,3-enediol. Vitamin $\mathrm{C}$ disebut antioksidan karena berfungsi sebagai donor elektron, sehingga dapat mencegah senyawa lain mengalami oksidasi. Saat vitamin C melepaskan elektron, ia menjadi radikal askorbil. Dibandingkan dengan radikal bebas lain, radikal askorbil ini relatif stabil dengan waktu paruh 10-5 detik dan tidak reaktif. Radikal bebas yang merugikan dapat berinteraksi dengan vitamin $\mathrm{C}$ sehingga radikal bebas yang merugikan tersebut mengalami reduksi dan vitamin $\mathrm{C}$ berubah menjadi radikal askorbil yang kurang reaktif. Proses reduksi radikal bebas reaktif menjadi senyawa yang kurang reaktif ini disebut free radical scavenging. Vitamin $\mathrm{C}$ merupakan free radical scavenging yang baik (Padayatty et al., 2003). Vitamin $\mathrm{C}$ (asam askorbat), bersifat larut dalam air dan terdapat di kompartemen sitosol sel, berperan sebagai donor elektron kepada radikal vitamin E yang muncul saat stres oksidatif.

$\alpha$-karoten dan $\beta$-karoten menyusun 90\% dari karotenoid. Banyak karotenoid bekerja sebagai antioksidan, yakni penangkap radikal bebas, teruatama peroksil dan hidroksil maupun oksigen singlet. $\beta$-karoten lebih efektif sebagai antioksidan biologis terutama pada bagian yang memiliki tekanan parsial oksigen rendah. $\beta$-karoten bekerja sinergis dengan vitamin $\mathrm{C}$ dan vitamin $\mathrm{E}$ (Silalahi, 2006).

Tanaman jambu biji (Psidium guajava L.) termasuk genus Psidium, famili Myrtaceae. Bagian yang paling penting dari jambu biji adalah buahnya. Buah yang sudah masak atau matang mengandung gizi yang cukup tinggi.Buah jambu biji biasanya dimanfaatkan sebagai buah segar atau olahan berupa jus (Rismunandar, 1989)

Buah jambu biji merah mengandung vitamin $\mathrm{C}$, vitamin $\mathrm{A}$, zat besi, kalsium dan fosfor. Kandungan vitamin $\mathrm{C}$ buah jambu biji merah 5 kali lebih banyak dibandingkan dengan jeruk (Kumar, 2012). Senyawa lain dalam buah jambu biji yang berfungsi sebagai antioksidan adalah karotenoid seperti beta- 
karoten, lycopene, beta-cryptoxanthin dan polifenol (Nascimento et al, 2010; Oliveira et al, 2010; Ordonez-Santos dan Vazquez-Riascos, 2010). Pada buah jambu biji merah juga dijumpai fosfat, oksalat asam, asam malat. Buah juga mengandung saponin, asam oleanolic, morin-3-O-lyxo pyranoside, morin-3-O- $\alpha$ Larabopyranoside dan flavonoid, guaijavarin dan quercetin. Minyak atsiri yang terdapat pada buah jambu biji merah diantaranya mengandung heksanal, -2Hexenal, 2,4-hexadienal, 3-Hexenal, 2-Hexenal, asam 3-metilbutanoik, (Z) -3Hexen-1-ol, 6- metil-5-hepten-2-satu, limonene, oktanol, etil octanoate terdapat pada buah jambu biji merah muda. Konstituen aromatik aktif dalam buah jambu biji merah muda didapati senyawa 3-penten-2-ol dan 2-butenil asetat (Kumar, 2012).

Sebagai salah satu bahan alam yang mengandung berbagai jenis antioksidan, aktivitas antioksidan buah jambu biji merah telah diuji di laboratorium dengan menggunakan metode DPPH (2,2-diphenil-1-picrilhidrazyl) dengan menggunakan spektrofotometer visible. Hasil penelitian menunjukkan ekstrak buah jambu biji merah memiliki IC50 $=45,5 \mu \mathrm{g} / \mathrm{mL}$ sedangkan vitamin C yang dijadikan sebagai standart memiliki IC50 $=25,8 \mu \mathrm{g} / \mathrm{mL}$ (Vyas et al, 2010).

Efek hepatoprotective dari aktivitas antioksidan daun jambu biji merah juga sudah dievaluasi secara invivo menggunakan tikus wistar. Hasil penelitian menunjukkan bahwa jambu biji merah dengan dosis $500 \mathrm{mg} / \mathrm{kg}$ peroral dapat menurunkan peningkatan kadar peroksidasi lipid dan memulihkan menjadi normal kadar enzim GPx, GSH, CAT dan SOD dan hasil ini juga didukung oleh hasil pemeriksaan secara histopatologi (Taju et al, 2011). Aktivitas antioksidan buah jambu biji merah juga telah diteliti terhadap peroksidasi lipid pada tikus hiperkolesterol. Hasil penelitian menunjukkan pemberian buah jambu biji merah dapat meningkatkan SOD serta menurunkan kadar MDA pada tikus hiperkolesterolemia (Maryanto, 2013).

VO2max adalah jumlah maksimal oksigen yang dapat dikonsumsi selama aktivitas fisik yang intens sampai akhirnya terjadi kelelahan. Karena VO2max ini dapat membatasi kapasitas kardiovaskuler seseorang, maka VO2max dianggap sebagai indikator terbaik dari ketahanan aerobik (Astorin et al, 2000 dan Welsman et al, 1996). VO2max juga dapat diartikan sebagai kemampuan maksimal seseorang untuk mengkonsumsi oksigen selama aktivitas fisik pada ketinggian yang setara dengan permukaan laut. VO2max merefleksikan keadaan paru, kardiovaskuler, dan hematologik dalam pengantaran oksigen, serta mekanisme oksidatif dari otot yang melakukan aktivitas.

Beberapa faktor yang dapat mempengaruhi nilai VO2max diantaranya: umur; jenis kelamin; suhu, keadaan latihan. Sementara itu faktor-faktor yang menentukan nilai VO2max adalah:

\section{a. Fungsi paru}

Pada saat melakukan aktivitas fisik yang intens, terjadi peningkatan kebutuhan oksigen oleh otot yang sedang bekerja. Kebutuhan oksigen ini didapat dari ventilasi dan pertukaran oksigen dalam paru-paru. Ventilasi merupakan proses mekanik untuk memasukkan atau mengeluarkan udara dari dalam paru. Proses ini berlanjut dengan pertukaran oksigen dalam alveoli paru dengan cara difusi. Oksigen yang terdifusi masuk dalam kapiler paru untuk selanjutnya 
diedarkan melalui pembuluh darah ke seluruh tubuh. Untuk dapat memasok kebutuhan oksigen yang adekuat, dibutuhkan paru-paru yang berfungsi dengan baik, termasuk juga kapiler dan pembuluh pulmonalnya. Pada seorang atlet yang terlatih dengan baik, konsumsi oksigen dan ventilasi paru total meningkat sekitar 20 kali pada saat ia melakukan latihan dengan intensitas maksimal (Fox , 2003). Dalam fungsi paru, dikenal juga istilah perbedaan oksigen arteri-vena $(A$ $V O 2$ diff). Selama aktivitas fisik yang intens, $A-V O 2$ akan meningkat karena oksigen darah lebih banyak dilepas ke otot yang sedang bekerja, sehingga oksigen darah vena berkurang. Hal ini menyebabkan pengiriman oksigen ke jaringan naik hingga tiga kali lipat daripada kondisi biasa. Peningkatan $A-V$ O2diff terjadi serentak dengan peningkatan cardiac output dan pertukaran udara sebagai respon terhadap olah raga berat (Pate et al, 1984).

\section{b. Fungsi kardiovaskuler}

Respon kardiovaskuler yang paling utama terhadap aktivitas fisik adalah peningkatan cardiac output. Peningkatan ini disebabkan oleh peningkatan isi sekuncup jantung maupun heart rate yang dapat mencapai sekitar 95\% dari tingkat maksimalnya. Karena pemakaian oksigen oleh tubuh tidak dapat lebih dari kecepatan sistem kardiovaskuler menghantarkan oksigen ke jaringan, maka dapat dikatakan bahwa sistem kardiovaskuler dapat membatasi nilai VO2max (Pate et al, 1984).

\section{c. Sel darah merah (Hemoglobin)}

Karena dalam darah oksigen berikatan dengan hemoglobin, maka kadar oksigen dalam darah juga ditentukan oleh kadar hemoglobin yang tersedia.Jika kadar hemoglobin berada di bawah normal, misalnya pada anemia, maka jumlah oksigen dalam darah juga lebih rendah. Sebaliknya, bila kadar hemoglobin lebih tinggi dari normal, seperti pada keadaan polisitemia, maka kadar oksigen dalam darah akan meningkat. Hal ini juga bisa terjadi sebagai respon adaptasi pada orang-orang yang hidup di tempat tinggi (Fox, 2003). Kadar hemoglobin juga dipengaruhi oleh hormon androgen melalui peningkatan pembentukan sel darah merah. Laki-laki memiliki kadar hemoglobin sekitar 1-2 gr per $100 \mathrm{ml}$ lebih tinggi dibanding wanita (Fox, 2003).

\section{d. Komposisi tubuh}

Jaringan lemak menambah berat badan, tapi tidak mendukung kemampuan untuk secara langsung menggunakan oksigen selama olah raga berat. Maka, jika VO2max dinyatakan relatif terhadap berat badan, berat lemak cenderung menaikkan angka penyebut tanpa menimbulkan akibat pada pembilang VO2. Jadi, kegemukan cenderung mengurangi VO2max (Pate et al, 1984).

\section{Metode}

Jenis penelitian adalah penelitian eksperimental dengan rancangan pre-test post-test, control group design dengan randomisasi sederhana. Lokasi penelitian dilakukan di Stadion Unimed, Laboratorium Fisiologi FIK-UNIMED dan Laboratorium Kesehatan Daerah Provinsi Sumatera Utara. Bahan penelitian diantaranya Jambu biji merah, larutan EDTA 1\%, Aquadest. Alat penelitian diantaranya:, Spectrofotometer, Alat-alat Gelas, Spuit, Blender. Jumlah atlet 
sebanyak 20 orang dengan kriteria mempunyai tingkat $\mathrm{VO}_{2}$ max yang baik, jenis kelamin laki-laki, umur 20-22 tahun, memiliki IMT yang baik, tidak perokok, tidak mengkonsumsi suplemen dan antioksidan 2 minggu sebelum dan selama penelitian, bersedia menjadi subjek penelitian.

Penelitian menggunakan 20 orang atlet yang memenuhi kriteria. Semua atlet dilakukan pemeriksaan hematologi untuk pemeriksaan haemoglobin dan pengukuran $\mathrm{VO}_{2}$ max. Selanjutnya atlet dibagi atas 2 kelompok yaitu kelompok eksperimen dan kelompok kontrol. Selama menjalani program latihan selama 2 bulan kelompok eksperimen diberi JBJBM 1x1 hari. Setelah menjalani program latihan semua atlet melakukan aktifitas fisik maksimal dengan melakukan bleep test. Selanjutnya kembali dilakukan pengukuran $\mathrm{VO}_{2}$ max dan haemoglobin. Pemeriksaan haemoglobin dilakukan dengan menggunakan spektrofotometer.

\section{Pembahasan}

\subsection{Data Berat Badan (BB) dan Tinggi Badan (TB)}

Kegiatan penelitian ini telah memeriksa sampel sebanyak sebanyak 20 orang. Usia sampel berkisar antara 19-20 tahun. Data rerata Berat Badan dan Tinggi Badan dapat dilihat pada tabel 1.

\section{Tabel 1. Nilai Rerata Berat Badan (BB) dan Tinggi Badan (TB) Sampel}

\begin{tabular}{|l|l|c|c|c|}
\hline \multicolumn{1}{|c|}{ Variabel } & Group & $\mathrm{n}$ & Mean & Sig \\
\hline \multirow{2}{*}{ Berat Badan } & Kontrol & 10 & 59.50 & \multirow{2}{*}{0.918} \\
\cline { 2 - 4 } & Eksperimen & 10 & 59.70 & \\
\hline Tinggi Badan & Kontrol & 10 & 1.66 & \multirow{2}{*}{0.109} \\
\cline { 2 - 4 } & Eksperimen & 10 & 1.68 & \\
\hline
\end{tabular}

Dari tabel 1 di atas setelah dianalisis menggunakan uji statistika independent samples t-test, Berat Badan dan Tinggi Badan kelompok kontrol dan eksperimen memberikan hasil tidak berbeda secara bermakna $(p>0,05)$. Tidak adanya perbedaan BB dan TB sampel dalam penelitian menggambarkan bahwa sampel memiliki kemampuan dan kekuatan fisik yang sama, sehingga dalam perlakuan penelitian diharapkan tidak terdapat perbedaan yang berarti yang dapat mempengaruhi hasil penelitian yang disebabkan oleh ketidaksamaan kemampuan dan kekuatan sampel.

1.2. Data Kadar Haemoglobin Sebelum dan Sesudah Pemberian Jus Buah Jambu Biji Merah Selama Latihan

Berdasarkan hasil penelitian yang dilakukan kadar $\mathrm{Hb}$ sebelum dan sesudah pemberian Jus Buah Jambu Biji Merah ditunjukkan pada gambar 1. 


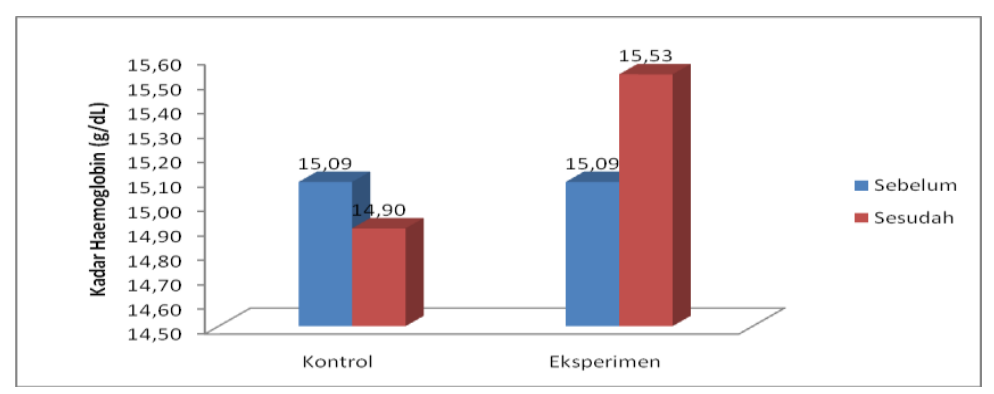

Gambar 1. Diagram Kadar Hb Sebelum dan Sesudah Pemberian Jus Buah Jambu Biji Merah Selama Menjalani Program Latihan

Dari hasil uji analisis data sebelum dan sesudah eksperimen diperoleh data adalah terdistribusi normal dan homogen baik kelompok kontrol maupun kelompok eksperimen. Hasil uji statistik dengan menggunakan uji t (Paired Samples Test) diperoleh hasil terdapat perbedaan kadar haemoglobin baik kelompok kontrol maupun kelompok eksperimen $(\mathrm{P}=0,000)$. Pada kelompok kontrol terjadi penurunan haemoglobin dari 15,09 g/dl menjadi 14,90, sementara kelompok eksperimen terjadi kenaikan $\mathrm{Hb}$ dari 15,09 g/dl menjadi 15,53. Jika dibandingkan perbedaan antara kelompok eksperimen dan kelompok kontrol setelah mengkonsumsi Jus Buah Jambu Biji Merah pada saat menjalani program latihan dengan uji t (Independent Samples Test) diperoleh perbedaan antara kelompok eksperimen dengan kelompok kontrol $(\mathrm{p}=0,001)$.

Penurunan kadar $\mathrm{Hb}$ pada kelompok kontrol sejalan dengan penelitianpenelitian yang dilakukan oleh banyak peneliti lain diantaranya penelitian yang dilakukan oleh (Senturk, et al., 2005) dimana pada penelitiannya didapati penurunan kadar $\mathrm{Hb}$ pada manusia setelah melakukan aktifitas fisik maksimal. Penurunan kadar $\mathrm{Hb}$ juga didapati pada tikus yang melakukan aktifitas fisik maksimal (Senturk,et al., 2001, Senturk, et al., 2004). Penurunan kadar hemoglobin ini disebabkan oleh meningkatnya jumlah sel-sel eritrosit yang rusak akibat latihan fisik maksimal (Senturk, et al., 2005). Sementara itu, peningkatan kadar Hb akibat pemberian Jus Buah Jambu Biji Merah terjadi akibat Jus Buah Jambu Biji Merah dapat mencegah terjadinya hemolisis pada membran sel darah merah yang diakibatkan peningkatan aktifitas fisik selama latihan. Buah jambu biji merah dapat mencegah proses lipolisis karena kandungan antioksidan yang ada pada buah jambu biji merah. Seperti diketahui buah jambu biji merah mengandung antioksidan mengandung vitamin $\mathrm{C}$, vitamin $\mathrm{A}$, zat besi, kalsium dan fosfor. Kandungan vitamin $\mathrm{C}$ buah jambu biji merah 5 kali lebih banyak dibandingkan dengan jeruk (Kumar, 2012). Senyawa lain dalam buah jambu biji yang berfungsi sebagai antioksidan adalah karotenoid seperti beta-karoten, lycopene, beta-cryptoxanthin dan polifenol (Nascimento et al, 2010;. Oliveira et al, 2010; Ordonez-Santos dan Vazquez-Riascos, 2010). Sebagai salah satu bahan alam yang mengandung berbagai jenis antioksidan, aktivitas antioksidan buah 
jambu biji merah telah diuji di laboratorium dengan menggunakan metode DPPH (2,2-diphenil-1-picrilhidrazyl) dengan menggunakan spektrofotometer visible. Hasil penelitian menunjukkan ekstrak buah jambu biji merah memiliki IC50 = $45,5 \mu \mathrm{g} / \mathrm{mL}$ sedangkan vitamin $\mathrm{C}$ yang dijadikan sebagai standart memiliki IC50 $=25,8 \mu \mathrm{g} / \mathrm{mL}$ (Vyas et al, 2010).

\subsection{Data Kadar $\mathrm{VO}_{2}$ max Sebelum dan Sesudah Pemberian Jus Buah Jambu Biji Merah Selama Latihan}

Berdasarkan hasil penelitian yang dilakukan kadar $\mathrm{VO}_{2} \mathrm{Max}$ sebelum dan sesudah pemberian Jus Buah Jambu Biji Merah ditunjukkan pada gambar 2.

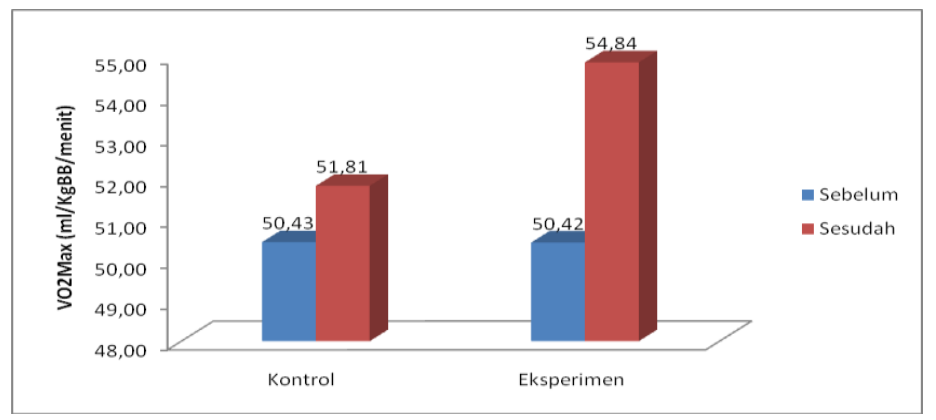

Gambar 2. Diagram Kadar $\mathrm{VO}_{2}$ max Sebelum dan Sesudah Pemberian Jus Buah Jambu Biji Merah Selama Menjalani Program Latihan

Hasil pengukuran nilai $\mathrm{VO}_{2} \max$ pretest kelompok kontrol sebesar $50,43 \mathrm{ml} / \mathrm{kgBB} / \mathrm{menit}$, sedangkan kelompok eksperimen diperoleh nilai $\mathrm{VO}_{2} \mathrm{max}$ sebesar 50,42ml/kgBB/menit. Dari hasil uji statistik menggunakan uji $\mathrm{t}$ (Independent Samples Test) diperoleh hasil bahwa tidak ada perbedaan antara kelompok eksperimen dengan kelompok kontrol dengan nilai $\mathrm{p}=0,988$ ( $\mathrm{p}>0,05)$. Hasil pengukuran nilai $\mathrm{VO}_{2}$ max setelah pemberian Jus Buah Jambu Biji Merah pada kelompok eksperimen mengalami peningkatan dari $50,42 \mathrm{ml} / \mathrm{kgBB} / \mathrm{menit}$ menjadi $54,84 \mathrm{ml} / \mathrm{kgBB} / \mathrm{menit}$ dan hasil uji statistik menunjukkan terdapat perbedaan dengan nilai $\mathrm{p}=0,000$. Pada kelompok kontrol juga mengalami peningkatan dari 49,43 $\mathrm{ml} / \mathrm{kgBB} /$ menit menjadi $49,77 \mathrm{ml} / \mathrm{kgBB} /$ menit dan dengan menggunakan uji t (Paired Samples Test) peningkatan nilai $\mathrm{VO}_{2}$ max ini adalah berbeda secara statistik dengan nilai $\mathrm{p}=0,023(\mathrm{p}<0,05)$. Sementara itu, dari hasil uji beda dengan menggunakan uji t (Independent Samples Test), nilai $\mathrm{VO}_{2}$ max post test antara kelompok kontrol dengan kelompok eksperimen menunjukan perbedaan secara bermakna dengan nilai $\mathrm{p}=0,163(\mathrm{p}>0,05)$.

Peningkatan $\mathrm{VO}_{2}$ max baik kelompok kontrol maupun kelompok perlakuan sebelum dan sesudah pemberian Jus Buah Jambu Biji Merah selama menjalani progam latihan diakibatkan karena kapasitas difusi paru orang terlatih lebih baik daripada orang yang tidak terlatih (Fox, 1988). Semakin baik kapasitas difusi paru, semakin besar volume gas yang berdifusi, maka akan bertambah baik 
kemampuan seseorang dalam melakukan pembebanan kardiorespirasi tanpa mengalami kelelahan yang berarti. Sehingga orang yang terlatih akan bernafas lebih lambat dan dalam, dan oksigen yang diperlukan untuk kerja otot pada proses ventilasipun berkurang. Akibatnya dengan jumlah oksigen yang sama, orang terlatih akan bekerja lebih efektif daripada orang yang tidak terlatih. Dengan demikian, selama melakukan aktifitas latihan secara rutin dalam penelitian ini akan meningkatkan nilai $\mathrm{VO}_{2}$ max. Peningkatan VO2max juga disebabkan bertambahnya kandungan $\mathrm{O} 2$ di dalam arteri dan vena, serta meningkatnya cardiac output maksimal. Kalau dibandingkan peningkatan $\mathrm{VO}_{2}$ max yang paling besar didapat pada kelompok eksperimen dibanding kelompok kontrol . Hal ini dapat dijelaskan pemberian Jus Jambu Biji Merah selama menjalani program latihan dapat mencegah terjadinya stressoksidatif yang dapat mengakibatkan peroksidasi lipid membran sel terutama sel darah merah. Hal ini dapat dilihat dari kadar $\mathrm{Hb}$ kelompok perlakuan lebih besar dibandingkan dengan kelompok kontrol. Seperti diketahui, $\mathrm{Hb}$ merupakan salah satu faktor yang mempengaruhi nilai $\mathrm{VO}_{2} \max$.

\section{Simpulan}

Pemberian Jus Buah Jambu Biji Merah selama menjalani program latihan dapat meningkatkan kadar Haemoglobin dan $\mathrm{VO}_{2}$ max pada aktifitas fisik maksimal.

\section{Rujukan}

Burton, G.W. and Traber, M.G. (1990). Vitamin E: antioxidant activity, biokinetics and bioavailability. Annual Review of Nutrition, 10, 357382.

Christopher, P.I.,Wenke, J.C., Nofal,T., Armstrong, R.B. (2004), Adaptation to lenghthening contraction-induced injury in mouse muscle. J.Appl.Physiol 97:1067-76.

Colgan, M. (1986). Effects of multinutrient supplementation on athletic performance. In Katch, F.I. (Ed) Sport, Health, and Nutrition, Human Kinetics: pp21-50

Daniel, R.M., Stelian, S., Dragomir, C. (2010), The effect of acute physical exercise on the antioxidant status of the skeletal and cardiac muscle in the Wistar rat. Romanian Biotechnological Letters. Vol. 15, No. 3, Supplement, p 56-61.

Dekkers JC, van Doornen LJ, Kemper HC. (1996). The role of antioxidant vitamins and enzymes in the prevention of exercise-induced muscle damage. Sports Med 21: 213-238.

Dekany,M., Nemeskeri, V., Gyore, I., Ekes, E., Gogl, A., Szots, G., Petrekanits, M., Taylor, A.W., Berkes,I., Pucsok, J., (2008). Physical performance and antioxidant effects Iin triathletes. Biology of Sport, Vol. 25. 101-114. 
Droge W. (2002). Free radicals in the physiological control of cell function. Physiol Rev. 82;47-95.

Eroglu, Y., Daglioglu, O. (2013). The effect of submaximal exercise on oxidant and antioxidant mechanisms in judokas and sedentary. International Journal of Sport Studies. Vol., 3 (5), 480- 486

Evans, W. J. (2000), Vitamin E, vitamin C, and exercise. Am J Clin Nutr, 72, $647 \mathrm{~S}-52 \mathrm{~S}$.

Gomez-Cabrera MC, Domenech E \& Viña J (2008) Moderate exercise is an antioxidant: upregulation of antioxidant genes by training. Free Radic Biol Med. 44, 126-131

Kumar,A. (2012). Importance for Life 'Psidium guava'. International Journal of Research in Pharmaceutical and Biomedical Sciences. Vol. 3 (1). 137143

Liang Y, Fang JQ, Wang CX, Ma GZ (2008). Effects of transcutaneous electric acupoint stimulation on plasma SOD and MDA in rats with sports fatigue. Zhen Ci Yan Jiu, 33: 120-123.

Lyle, N., Gomes, A., Sur, T., Munshi, S., Paul, S., Chatterjee S. and Bhattacharyya, D. (2009). The role of antioxidant properties of Nardostachys jatamansi in alleviation of the symptoms of the chronic fatigue syndrome. Behavioural Brain Res., 202: 285-290.

Maryanto,S. (2013). The effects of red guava (Psidium guajava L) fruits on lipid peroxidation in hypercholesterolemic rats. Basic Research Journal of Medicine and Clinical Sciences. Vol. 2(11) pp.116-121

Nascimento RJ, Araújo CR, Melo EA (2010). Antioxidant from agriindustrial wastes of the guava fruits (Psidium guajava L) Alim Nutr. 21: 20916Ostojic, S.M., Stojanovic, M.D., Djordjevic, B., Jourkesh, M., Vasiljevic, N. (2008). The Effect of a 4-Week Coffeberry Suplementation on Antioxidant Status, Endurance, and Anaerobic Performance in College Athletes. Research in Sports Medicine, 16: 281294

Oliveira D S, Lobato AL, Ribeiro SM, Santana AM, Chaves JB (2010). Carotenoids and Vitamin $\mathrm{C}$ during Handling and Distribution of Guava (Psidium guajava L.), Mango (Mangifera indica L.), and Papaya (Carica papaya L.) at Commercial Restaurants. J. Agric Food Chem. 58: 61666172

Rismunandar. 1989. Tanaman Jambu Biji. Sinar Baru, Bandung.

Rosidi,A., Khomsan, A., Setiawan, B., Riyadi,H and Briawan,D. (2013). Effect of Temulawak (Curcumin xanthorrhiza Roxb) Extract on Reduction Of MDA (Malondialdehyde) Levels of Football Athletes. Pakistan Journal of Nutrition. 12 (9): 842-850

Senturk, U. K., Gunduz, F., Kuru, O., Aktekin, M. R., Kipmen, D., Yalcin, O., Bor-Kucukatay, M., Yesilkaya, A. \& Baskurt, O. K. (2001), Exerciseinduced oxidative stress affects erythrocytes in sedentary rats but not latihan fisiktrained rats. J Appl Physiol, 91, 1999-2001.

Senturk, U. K., Gunduz, F., Kuru, O., Kocer, G., Ozkaya, Y. G., Yesilkaya, A., Bor Kucukatay, M., Uyuklu, M., Yalcin, O. \& Baskurt, O. K. (2004), 
Effect of oxidant vitamin treatment on the time course of hematological and hemorheological alteration after an exhausting exercise episode in human subject. J Appl Physiol, 98, 1272-79.

Senturk, U. K., Gunduz, F., Kuru, O., Kocer, G., Ozkaya, Y. G., Yesilkaya, A., Bor Kucukatay, M., Uyuklu, M., Yalcin, O. \& Baskurt, O. K. (2005), Exerciseinduced oxidative stress leads hemolysis in sedentary but not trained humans. J Appl Physiol, 99, 1434-41.

Silalahi, J. (2006). Makanan Fungsional. Penerbit Kanisius Yokyakarta. Halaman $38-56$

Sinaga, F.A (2012). Pengaruh Pemberian Vitamin E Terhadap Kadar Malondialdehid, Hemoglobin dan $\mathrm{VO}_{2} \mathrm{Max}$ Selama Latihan Pada Atlet Sepakbola FIK UNIMED. Jurnal Penelitian Saintika, Vol.12 No.2. 153164

Sinaga, F.A (2013). Pengaruh Pemberian Virgin Coconut Oil (VCO) Terhadap Parameter Hematologi, Kadar Malondialdehid dan Daya Tahan Tikus (Rattus Norvegicus Galur Sprague Dawley) Pada Aktifitas Fisik Maksimal. Proceeding, International Scientific Seminar On Sport And Sportsciences, ISBN: 978-602-98603-9-9 p. 226-238

Souza, C.F., Fernandes, L.C. and Cyrino, E.S. (2006). Production of reactive oxygen species during the aerobic and anaerobic exercise. Rev Bras Cineantropom. Desempenho Hum, Vol.8, 2006. pp. 102-109.

Stankovic, M., and Radovanovic, D, (2012), Oxidative Stress and Physical Activity, SportLogia, 8(1), 1-20

Taju, G., Jayanthi, M., Majeed,S.A. (2011). Evaluation of Hepatoprotective and Antioxidant activity of Psidium Guajava Leaf Extract against Acetaminophen Induced Liver Injury in Rats. International Journal of Toxicology and Applied Pharmacology. 1 (2): 13-20

Thirumalai, T., Viviyan T. S., Elumalai,E.K., David, E. (2011). Intense and exhaustive exercise induce oxidative stress in skeletal muscle, Asian Pacific Journal of Tropical Disease 63-66

Urso, M.L., Clarkson, P.M. (2003), Oxidative stress, exercise, and antioxidant supplementation. Toxicology 189(1-2):41-54

Vyas, N., Tailang, M., Gavatia, N.P. and Gupta, B.K (2010). Antioxidant Potential Of Psidium Guajava Linn. International Journal of PharmTech Research. Vol.2, No.1, pp 417-419

Vina J, Gomez-Cabrera MC, Lloret A, Marquez R, Minana JB, Pallardo FV (2000). Free radicals in exhaustive physical exercise: mechanism of production and protection by antioxidants. IUBMB Life, 50: 271-7.

Wang, L., Zhang, H.L., Zhou, Y.J., Ma, R., Lv, J.Q., Li, X.L., Chen, L.J. and Yao, Z. (2008). The decapeptide CMS001 enhances swimming endurance in mice. Peptides, 29: 1176-1182.

Winarsi,H.2007. Antioksidan Alami dan Radikal Bebas. Penerbit Kanisius. Yogyakarta 